\title{
PEMIKIRAN EKONOMI ABÛ YÛSUF DAN IBN ADAM: Eksplorasi Awal Konsep Sumber Keuangan Negara
}

\author{
Oleh: Asmuni Mth ${ }^{*}$
}

\section{Abstract}

Abû Yûsûf and Ibn Adam have the different methodology in writing the al-Kharaj. Abû Yûsuff more rationally in revealing the arguments and his economic jurisprudence formulation more realistic and independent. While Ibn Adam just refers to the ahâdits and ahdâts without any external and internal critique to them. Al-Kharaj may mean the source of state income and land tax. Al-Kharaj and aljizyah loaded for the zimmi, while for Muslim people obliged to submit the zakat. al-Kharaj, jizyah and zakat contain the close meaning. However, the inherent characters of zakat deny the zakat its self from al-kharaj or al-jizyah.

\section{a)}

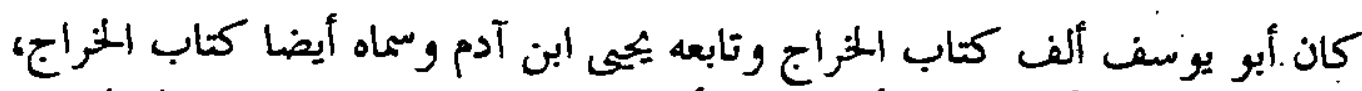

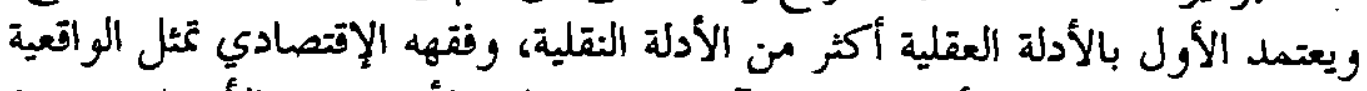

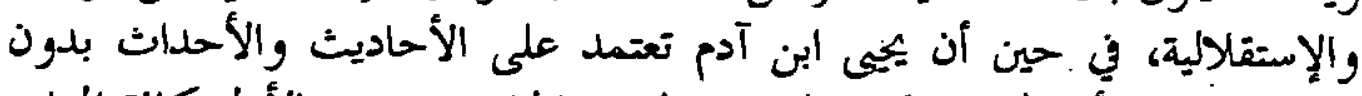

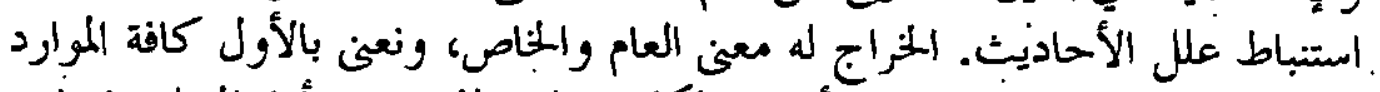

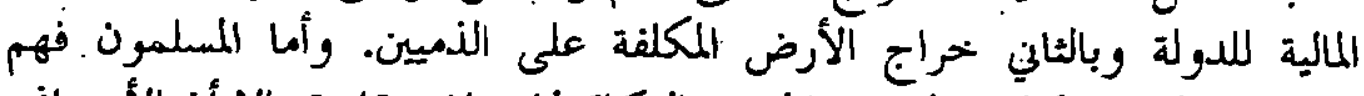

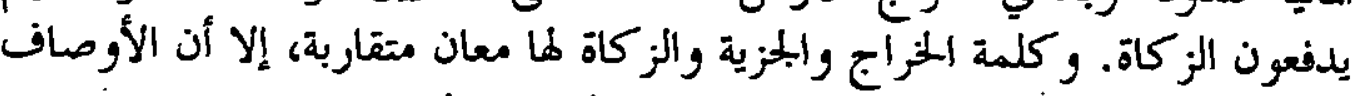

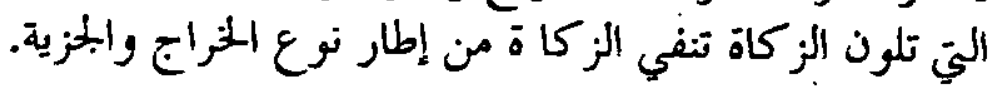

Kata kunci: al-kharaj, al-jizyah, zakat, zimmi.

- Penulis adalah Dosen FIAI UII dan Kabid Akademik MSI UII Yogyakarta. 


\section{A. Pendahuluan}

Abû Yûsuf lahir pada tahun $113 \mathrm{H}$, pernah tinggal di Kufah dan di Bagdad, meninggal pada tahun $182 \mathrm{H}$. Menurut penuturannya beliau menjadi murid Abû Hanifah selama 17 tahun ${ }^{1}$ dan sejumlah ulama terkemuka pada masa itu. ${ }^{2}$ Beliau juga tercatat sebagai murid dari Ibn Abi Laila, imam Malik dan sejumlah ulama lainnya. Panggilan populernya adalah $Q \hat{a} d h \hat{\imath} Q u d h a ̂ t$ (hakim agung) yaitu jabatan yang disandangnya pada masa kekuasaan khalifah Harun al-Rasyid. Perhatiannya banyak terfokus pada keuangan umum dan peran negara, pekerjaan umum, dan perkembangan pertanian. ${ }^{3}$ Ia pun dikenal sebagai penulis pertama buku perpajakan yang dinamainya Kitab al-Kharaj. ${ }^{4}$

Beberapa tahun pasca Abû Yûsuf, muncul pula kitab al-kharaj $j^{5}$ karya Yahya Ibn Adam al-Qurasyi (140 H/-203/818 M). Buku ini termasuk yang ketiga dalam bidang ekonomi setelah kitab al-Amwâl karya Abû Ubaid. ${ }^{6}$ Walaupun kebanyakan ahli biografi ulama (al-tarâjum) tidak mengetahui tahun lahir Ibn Adam, namun dapat dipastikan beliau hidup pada abad ke II H, semasa dengan Abû Yûsuf dan meninggal tahun $203 \mathrm{H}$. Jumlah guru Ibn Adam menurut catatan Ahmad Syakir ${ }^{7}$ sebanyak 90 orang antara lain al-Hasan Ibn Soleh. Mereka kemudian menjadi mata rantai (sanad) hadis yang memperkuat kualitas akademik al-kharaj. Muridnya antara lain imam Ahmad Ibn Hanbal, Ishaq Ibn Rahawaih, dan Ali Ibn al-Madini. Beliau tercatat sebagai ahli hadis yang mendapat pujian dari Ibn Ma'in, Nasa'i, dan Ali ibn al-Madini. Kalau Abû Yûsuf dikenal ahli fiqh aliran $r a^{\prime} y$, maka Ibn Adam akrab dengan argumen-argumen tekstual terutama hadis, keputusan maupun kebijakan para khalifah terdahulu.

Uraian di atas memunculkan beberapa pertanyaan antara lain: metode apakah yang digunakan oleh Abû Yûsuf dan Ibn Adam dalam menulis karya al-kharaj? Adakah perbedaan konsep al-kharaj menurut mereka? Tulisan ini akan berusaha untuk menjawab kedua pertanyaan tersebut.

'Al-Shumairy, Akhbâr Abi Hanîfah wa Ashäbihî, hal. 97.

'Antara lain Atho' seorang tabi'in senior, ibn Saib, al-A'masy, Hisyam ibn Urwah.

${ }^{3}$ Muhammad Abdul Mannan, Ekonomi Islam: Teori dan Praktek, hal. 24

${ }^{4}$ Lihat Abû Yusuf Ya'qub Ibn Ibrahim, 1979, al-Kharaj, Beirut: Dâr al-Ma'rifah. Buku ini juga pernah dipublikasikan oleh al-Mathba'ah Salafiyah di Kairo pada tahtun $1382 \mathrm{H}$.

'Yahya Ibn Adam al-Qurasyi, 1979, Kitab al-Kharaj, tahqiq Ahmad Muhammad Syakir, Beirut Dâr al-Ma'rifah. Buku ini juga pernah dipublikasikan oleh al-Mathba'ah Salafiyah di Kairo pada tahun $1377 \mathrm{H}$.

'Abû 'Ubaid al-Qosim Ibn Salam, 1353 H., al-Amwâll, Tahqîq Muhammad Hamid al-Faqy, Kairo: Dâr al-Kutub al-Misriyah.

'Lihat catatan pendalıuluan Ahmad Syakir dalam kitab al-kharaj, hal 1-4. 


\section{B. Metode Abû Yûsuf dan Ibn Adam dalam al-Kharaj}

Abû Yûsuf menjadi salah satu dari dua referensi utama fiqh dalam madzhab Hanäi ${ }^{8}$. Pengetahuannya tentang hadis juga tidak dapat diremehkan. Ini terlihat dalam kitab al-Atsar karya putranya Yûsuf. Kitab ini sarat dengan wacana fiqh Abû Hanifah dan Abû Yûsuf.'

Dalam bidang ekonomi, terutama dalam kitab al-kharaj, Abû Yûsuf pun menggunakan metode-metode tersebut. Kitab al-Kharaj, merupakan jawaban atas pertanyaan-pertanyaan yang diajukan oleh khalifah Harun al-Rasyid dan pertanyaanpertanyaan yang dibuat sendiri oleh Abû Yûsuf. Jawaban atas semua pertanyaan tersebut diperkuat oleh dalil-dalil aqli dan naqlî sehingga lebih unggul secara akademik dari pada kitab al-Kharaj karya Ibn Adam yang hanya diperkuat oleh dalil-dalil naqli tanpa memberi kesempatan kepada nalar.

Metode Ibn Adam yang mengunggulkan dokumentasi (tausiq) riwayat telah menyeretnya menggunakan hadis $d h a$ 'îf, dan menukil pendapat sahabat dan tabi' in dalam jumlah yang cukup banyak tanpa melakukan kritik eksternal (sanad) dan internal (matn) terhadapnya. Sebaliknya, Abû Yûsuf menggunakan pendekatan rasional dalam menyimpulkan 'ilal al-hadits. Sehingga kualitas hadis dalam al-kharaj karya Abû Yûsuf lebih shahîh ketimbang dalam kitab al-kharaj karya Ibn Adam. Tentu saja Abû Yûsuf tidak mengabaikan praktek faktual para sahabat (a'mal al-shahâbah) sejauh itu relevan dengan situasi yang ada mengingat kemaslahatan umum selalu menjadi pertimbangan utama.

Istilah $a l-$ kharaj $^{10}$ dalam prespektif Abû Yûsuf mengandung dua makna:pertama, makna yang berdimensi umum yaitu al-amwâl al-'âmmah (keuangan umum), atau sumber pendapatan negara. Hal ini terlihat ketika Abû Yûsuf mendiskusikan tema-tema yang berkaitan dengan sumber pendapatan negara seperti ghanimah, fai', al-kharaj, al-jizyah, dan harta-harta yang berkedudukan sebagai pengganti seperti al-kharaj seperti 'usyur al-tijârah, dan shadaqah.

${ }^{8}$ Referensi kedua adalah Muhammad Ibn Hasan al-Syaibani.

${ }^{9}$ Hamad Abdurrahman al-Junaidal, $1406 \mathrm{H}$., Manâhij al-Bâhitsînfî al-Iqtishâd al-Islâmî, Syarikah al-'Ubaikan li al-Thoba'ati wa al-Nasyr, hal. II/131.

${ }^{10}$ Dalam tradisi fuqahâ' al-kharaj (land tax) bentuk tunggal, sedangkan bentuk jamaknya akhrijah dan akhraj artinya pajak yang diambil oleh negara atas tanah yang ditaklukkan secara kekerasan, atau tanah yang pemiliknya melakukan perdamaian dengan kaum muslim. Al-Kharaj dua macam: Kharaj wazifah atau dalam istilah fiqh ekonomi modern disebut nidlâm al-masâhah yaitu pajak yang ditetapkan atas tanah; Kharaj Muqâsamah atau nizam al-muqâsamah yaitu pajak hasil pertanian yang ditetapkan oleh pemerintah dalam jumlah tertentu. Lihat Muhammad Rowas Qol'aji dan Hamid Sodiq Qunaibi, 1408 H/1988 M, Mu'jam lugât al-Fugahâ' 'Arabi Inklizi, cet. II, Beirut: Dâr al-Nafa'is, hal. 194. 
Kedua, makna al-kharaj yang berdimensi khusus terlihat ketika beliau menyebutkan sewa tanah atau kompensasi atas pemanfaatan tanah. Kedua dimensi makna al-kharaj tersebut ditemukan pula dalam karya Ibn Adam dan Abû Ubaid. Dengan demikan, istilah al-amwâl sinonim dengan istilah al-kharaj yaitu keuangan umum atau sumber pendapatan negara. Pemaknaan al-kharaj secara sempit dan khusus, kata Dhiya' al-Dîn al-Rîs muncul dan dipelopori oleh fuqahâ' pasca Abû Yûsuf, tetapi pemunculan tersebut tidak mempengaruhi makna dasar al-kharaj. ${ }^{11}$

\section{Figh Ekonomi Abû Yûsuf}

Abû Yûsuf adalah orang pertama kali memperkenalkan konsep perpajakan di dalam karyanya al-kharaj. Kitab ini, ditulis atas permintaan Khalifah Harun al-Rasyid, ketika dia ingin mengatur sistem Bait al-mâl, sumber pendapatan negara ${ }^{12}$ dan cara pendistribusiannya, ${ }^{13}$ dan untuk menghindari manipulasi, kedhaliman, serta untuk mewujudkan kepentingan penguasa.

Muatan konseptual al-Kharaj dan visi strategisnya terhadap kebijakan sumber pendapatan negara mencerminkan keunggulan akademik Abû Yûsuf dalam bidang ekonomi, dan pengalamannya menjabat sebagai hakim agung. Interaksinya dengan penguasa dari satu sisi, dan kepakarannya dalam ilmu fiqh dari sisi lain, telah menempatkan kitab al-kharaj sebagai karya monumental dan komperehensif. Keberadaan kitab alkharaj juga mempertegas bahwa ilmu ekonomi adalah bagian tak terpisahkan dari seni dan manajemen pemerintahan dalam rangka pelaksanaan amanat yang dibebankan rakyat kepada pemerintah untuk mensejahterakan mereka. Dengan kata lain, tema sentral pemikiran ekonominya menekankan pada tanggungjawab penguasa untuk mensejahterakan rakyatnya. Ia adalah peletak dasar prinsip-prinsip perpajakan yang di kemudian hari "diambil" oleh para ahli ekonomi sebagai canons of taxation. ${ }^{14}$

Sedangkan pemikiran kontroversialnya ada pada sikapnya yang menentang pengendalian dan penetapan harga (tas 'îr). Beliau berbeda dengan fuqahấ' lain, Ibn Taymiyyah misalnya, memperjelas secara lebih rinci dengan menyatakan bahwa $t a s^{\prime} i r$ dapat dilakukan pemerintah sebagai bentuk intervensi pemerintah dalam mekanisme

"Lihat Dhiya' al-Dîn al-Ris, al-Kharaj wa al-Nudlûm al-Islâmiyyah li al-Daulah alIslamîyah, dalam al-Junaidal, hal. 137.

${ }^{12}$ Sumber pendapatan negara antara lain al-kharaj, al-'zusy'ur, dan al-jizyah jibayat, alshadagat wa al-jawali (al-jizyah).

${ }^{13}$ Lihat Muhib al-Dîn al-Khatib, al-Qadli AbũYusuf Ya'qub Ibrahim (112-182H), Kitấb alKharaj, dalam al-Junaidal, hal, II/139.

${ }^{14}$ Juhaya S. Praja, Perkembangan Pemikiran EkonomiSyariah, bahan kuliah Pendekatan dalam Pengkajtan Islam Magister Studi Islam Universitas Islam Indonesia Yogyakarta. 
pasar. Lebih lanjut Taimiyyah mempertegas kondisi-kondisi tertentu, kapan tas 'îr dapat dilakukan dan tidak boleh dilakukan oleh pemerintah dan bahkan kapan pemerintah wajib melakukannya. ${ }^{15}$

Dapat dipastikan, bahwa konsep "ekonomi makro" tidak ditemukan dalam alkharaj karya Abû Yûsuf, dan juga belum dikenal di dunia Barat sampai beberapa abad pasca Abû Yû̀suf. Kegiatan perkonomian, kata Abû Yûsuf merupakan fenomena yang selalu berubah-ubah (dlawâhir tsanawiyyah) dan bersumber dari aktifitas kolektif masyarakat muslim. Faktor-faktor yang mempercepat kegiatan perekonomian tidak sama dari segi tingkat kepentingan dan kekuatannya. Pertama, mewujudkan undang-undang tertinggi yang dengannya dapat memerintah dengan pertolongan Tuhan. Kedua, usaha untuk memenuhi kebutuhan material dan keinginan-keinginan lainnya. Ketiga, inisiatif atau keinginan penguasa. Oleh karena itu, kata Abû Yûsuf, fenomena perekonomian tidak selalu berhubungan secara langsung dengan sebab akibat (undang-undang tentang prekonomian). Hubungan biasanya bersifat tidak langsung karena melalui kehendak tertinggi, atau kehendak wakil Tuhan di permukaan bumi dalam bentuk masyarakat muslim, penguasa atau Jainnya. Para khalifah Tuhan memiliki wewenang untukmengambil keputusan berkaitan dengan sejumlah fenomena-fenomena perekonomian seperti perbaikan tanah dan lain-lain.

Sumber ekonomi, tegas Abû Yûsuf berada pada dua tingkatan: tingkat pertama meliputi unsur-unsur alam (antara lain air dan tanah). Unsur-unsur ini paling kuat dan melakukan produksi secara mandiri. Tingkatan kedua tenaga kerja. Tingkatan yang kedua ini berperan kurang maksimal dan tidak rutin seperti perbaikan dan pemanfaatan tanah, membuat sistem irigasi dan lain-lain. ${ }^{16}$

Abû Yûsuf tidak banyak menyentuh persoalan fakir miskin (fuqarâ') dan tidak memunculkan konsep kelas sosial. Deskripsi masyarakat yang dibuat Abû Yûsuf, mencerminkan bahwa hubungan produksi dari satu sisi merupakan hubungan antara umat Islam dengan kaum zimmi dalam Dôr al-Islâm atau hubungan umat Islam dengan' komunitas non muslim dalam dâr al-harab. Dalam hubungan model pertama pendapatan bersumber dari al-kharaj dan al-jizyah. ${ }^{17}$ Sedangkan hubungan model kedua,

${ }^{\text {i5 } T e n t a n g ~ k o n s e p ~ t a s ' i r ~ y a n g ~ l e n g k a p ~ l i h a t ~ k a r y a ~ g u r u ~ k a m i ~ Q a h t h a n ~ A b d u r r a h m a ̂ n ~ a l-~}$ Dûrî, 1394 H/1974 M., al-Ihtikâr wa Atsaruhûfi al-Fiqh al-Islâmî. Cet. I, Bagdad: Mathba'ah alUmmah.

${ }^{16}$ Sebetulnya produksi dalam pengertian membuat barang baku (setengah jadi) menjadi produk final melalui kerja, tidak banyak menarik perhatian Abû́ Yûsuf termasuk pada proses permulaan seperti ihyâ' al-mawî́d.

${ }^{17}$ Jizyah (poll tax) pajak diri yang ditetapkan oleh negara terhadap kaum zimmi sebagai kompensasi atas perlindungan keselamatan. Lihat Qal'aji dan Qunaibi, Mu'jam, hal. 164. 
pendapatan bersumber dari al-ghanîmah yang sebagiannya didistribusikan untuk Bait al-mâl. Selain itu, pemerintah juga menarik bea cukai dari pedagang kaffir harbi atas barang dagangan mereka yang masuk ke negara Islam. Adapun umat Islam diwajibkan ' untuk mengeluarkan zakat sebagai bentuk solidaritas sosial mereka sesama muslim yang membutuhkan.

Kekuasaan menurut Abû Yûsufterdiri dari tiga unsur yaitu: umat Islam, pemimpin (imam), lembaga-lembaga negara atau pemerintahan antara lain al-jaisy, al-dawâwîn. Mereka dibebani dengan misi ekonomi yang paling fundamental seperti menetapkan jizyah, membagi ghanimah, menetapkan gaji dan tunjangan, memberikan tanah pinjaman (gaduhan), membuat sistem irigasi dan memperbaiki tanah.

Adapun konsep kepemilikan sangat luas dan fleksibel meliputi penanaman modal (istiglâl) yang memberikan hak kepada pemiliknya untuk mengambil sebagian atau semua keuntungan, kepemilikan secara aktual, kepemilikan individu dan kepemilikan khusus seperti barang bergerak, kepemilikan umum dan kepemilikan bersama yang diatur oleh pemerintah, kepemilikan terhadap budak. Jenis-jenis kepemilikan ini memiliki karakteristik yang tidak permanen.

Terdapat catatan penting dan umum khususnya susunan kategori yang dikemukakan Abû Yûsuf dalam kitab al-kharaj, yaitu agama, ekonomi dan militer. Hal ini terlihat pada konsep hubungan produksi yang fundamental, hubungan pajak tanah dan pajak diri.

Unsur-unsur keagamaan dapat dilihat dari hubungan komunitas muslim dan komunitas zimmi. Unsur-unsur ekonomi terlihat bahwa pendapatan berpindah dari yang kedua (kaum zimmi) ke yang pertama (kaum muslim). Unsur-unsur militer terlihat bahwa hubungan-hubungar tersebut hasil dari perjanjian atau kesepakatan sebagai konsekuensi kemenangan dalam berperang.

\section{Fiqh Ekonomi Ibn Adam}

Kitab al-Kharaj Karya Ibn Adam tidak jauh berbeda dengan al-Kharaj karya Abû Yûsuf kecuali pada aspek metode konstruksi terhadap dalil. Abû Yûsuf menekankan argumen rasional, sementara Ibn Adam mengacu pada ahâdits dan ahdâts (hadis dan kebijakan politik pemerintah dalam menghadapi kasus-kasus sebelumnya). ${ }^{18} \mathrm{Karya}$ Ibn Adam sarat dengan berbagai perbedaan pendapat. Metode penulisan seperti ini, dari satu sisi sangat bagus karena merekam berbagai wacana secara komprehensif. Namun dari sisi lain, dapat membingungkan pembaca karena penulis tidak mengemukakan pendapat secara cermat dan independen yang mencerminkan kepribadjan ilmiahnya. Pemandangan seperti ini dalam karya Ibn Adam, terlihat sangat mengasyikkan. 
Konsep kebersamaan dalam kehidupan ekonomi (musytarakiyât al-hayât aliqtishâdiyyah) dalam karya Ibn Adam muncul ketika beliau mendiskusikan penduduk pedesaan yang satu sama lain saling menjamin pada pajak tanah (jizyat al-ardh) di hadapan kaum muslim yang saling menjamin pula. ${ }^{19} \mathrm{Ibn}$ Adam selalu menegaskan almusytarakiyyah (kebersamaan) dengan berbagai pihak yang berbeda agama seperti (umat muslim, kaum zimmi dan kebersamaan yang bersifat lokal seperti penduduk desa dan kota. Beliau juga sering menegaskan berbagai macam perlakuan pada jibâyah (penarikan pajak) sesuai dengan karakteristik daerah, bentuk kesepakatan, perjanjian dan keadaan penduduk. ${ }^{20}$

Ibn Adam menyebutkan konsep al-qimah (harga) dan al-nafaqah (beaya hidup) atau al-takliffah. Kedua konsep tersebut hampir tidak ada di benak Abû Yûsuf. Hal ini menunjukkan bahwa Ibn Adam menyadari pentingnya keberadaan pasar sebagai unsur perekonomian makro dan merupakan unsur yang menyatukan antara elemen-elemen yang membentuk al-musytarakiyah tersebut. ${ }^{21}$

Baik Ibn Adam maupun Abû Yûsuf sepakat pada unsur-unsur yang menggerakkan prekonomian, dan urutan prioritas sumber-sumber ekonomi: al-thabî' $a h$ (sumber alam) dan al-'amal al-insânî (tenaga kerja). Harta yang dibebankan atas tanah akan menjadi al-kharaj (jizyah) apabila dapat dijangkau oleh air sungai yang berstatus kharaj. ${ }^{22}$ Pernyataan ini menegaskan karakteristik air yang dapat mélakukan aktivitas produksi secara mandiri.

Akan tetapi yang paling penting dalam karya Ibn Adam adalah konsep yang berkaitan dengan hubungan-hubungan internal atau dalam istilah modern disebut "hubungan-hubungan produksi (hubungan-hubungan yang berimplikasi pada pembagian dan pendistribusian hasil produksi masyarakat). Hal ini tentu sangat wajar karena judul karyanya adalah al-kharaj yaitu pajak tanah (jizyat al-ardh). Ibn Adam seperti juga halnya dengan Abû Yûsuf memasukkan konsep pajak diri (jizyat al-ra'as), ganîmah, al-'usyur shadaqah, zakat dan bea cukai, sebagai sarana pendapatan umat Islam pada masa itu.

Menurut Ibn Adam al-kharaj adalah lembaga yang eksis pada masa imperium Persia sebelum bangsa Arab menaklukkan dan menguasai tanah Sawad:

"Mereka meninggalkan tanah dan penduduk Sawad dan mewajibkan kepada penduduknya untuk membayar jizyah. Mengukur lahan (tanah) yang mereka miliki, kemudian menetapkan pajaknya. Selain itu, mereka

\footnotetext{
${ }^{19} \mathrm{lbn}$ Adam, op, cit., hal. 7

${ }^{20} \mathrm{Ibid}$., hal 68.

${ }^{21}$ Ibid., hal. 114.

${ }^{22} I$ Ibid., hal 11.
} 
mengambil tanah yang belum dimiliki oleh seseorang dan menyerahkannya kepada imam atau pengutasa. ${ }^{23}$

Yahya Ibn Adam mengisyaratkan bahwa tanah yang ditaklukkan secara kekerasan beralih status menjadi tanah kharaj. Tetapi kalau pemiliknya menjadi penganut agama Islam, mereka dibebaskan dari kewajiban jizyat al-ra'as (pajak diri). ${ }^{24}$ Pendapat ini membuka jalan bagi fiqh di Mesir. Misalnya mayoritas tanah pertanian selalu berstatus tanah kharaj meskipun penduduk Mesir telah menjadi penganut Islam dan banyak meninggalkan sektor pertanian. ${ }^{25}$

Kharaj mengandung dimensi sosial bagi al-musytarakât al-qurowiyah (komunitas pedesaan). Kaum zimmi yang status ekonominya cukup bagus bertanggung jawab atas mereka yang miskin atau orang yang meninggal dunia. Baik Ibn Adam maupun Abû Yûsuf sama-sama berpendapat bahwa al-kharaj menjadi sumber pendapatan negara terbesar. ${ }^{26}$ Namun demikian Ibn Adam juga berpendapat bahwa jizyat al-ra'as (pajak diri) dapat dikenakan terhadap kaum Yahudi baik laki-laki maupun perempuan, meskipun ini berupa pengecualian. ${ }^{27}$

Menurut Ibn Adam, pedagang muslim atau kaum zimmi yang berdomisili di dâr al-Islâm tidak dibebankan untuk membayar bea cukai. Pendapat ini sejauh pengetahuan kami hanya dikemukakan oleh Ibn Adam. Sedangkan penulis lain seperti Abû Yûsuf dan Imam Syafi'i mewajibkan pajak kepada semua pedagang tanpa melihat agama yang dianut dan tempat tinggal mercka, walaupun pajak yang dibebankan tersebut secara kuantitatif terdapat perbedaan sesuai dengan status dan tingkat keberadaan mereka dalam negara Islam. Kedudukan pengusaha dari kaum zimmi atau dari kaum harbi misalnya, sangat istimewa bila dibandingkan dengan kedudukan petani dari kaum zimmi. Karena dua kelompok pertama membayar 'usyr (sepersepuluh) atau separuhnya. Beban atas pembayaran tersebut tidak akan mencerminkan status mereka menjadi rendah di tengah masyarakat. Sementara kelompok ketiga (kalangan petani dari kaum zimmi) membayar al-kharaj sebagai salah satu bentuk al-jizyah. Membayar al-jizyah mencerminkan keberadaan status mereka yang rendah di tengah masyarakat. Adapun Ibn Adam memposisikan pengusaha kaum zimmi lebih istimewa hampir sejajar dengan pengusaha muslim karena mereka dibebaskan dari kewajiban pajak. Meskipun Ibn Adam sendiri dalam halaman berikutnya menyebutkan kebijakan Umar Ibn Khattab menetapkan

\footnotetext{
${ }^{23}$ Ibn Adam, op. cit., hal. 7-8.

${ }^{24}$ Ibid., hal. $7,120,121$

${ }^{25} \mathrm{Sa}$ 'd, op. cit., hal. 33 .

${ }^{26} \mathrm{Ibid}$., lual. 59.

${ }^{27}$ Ibid., hal. 53 .
} 
(" 'usyur atau separuhnya dari harta perdagangkan kaum zimmi"). ${ }^{28}$ Tetapi peñdapat Umar ini tidak dijadikan referensi oleh Ibn Adam.

Adapun umat Islam diwajibkan untuk mengeluarkan zakat. Uraian tentang zakat terutama syarat, hukum dan lainnya banyak terungkap dalam karya Ibn Adam dan karya fugah $\hat{a}$ ' pada umumnya. ${ }^{29}$ Hanya saja sifat-sifat yang inheren pada zakat telah menafikan sifat al-dharibah atau al-jibâyah dalam zakat itu sendiri. Kalau al-dharîbah dan $a l$ jibôyah merupakan kewajiban yang ditetapkan negara kepada rakyat, maka zakat berada pada ruang lingkup hubungan-hubungan solidaritas yang lebih sederhana bagi setiap individu muslim. Oleh karena itu, meskipun ada hubungannya dengan pendapatan, namun agak sulit menempatkan zakat sebagai sumber pendapatan negara.

Kesimpulan tersebut diperkuat oleh perkataan Ibn Adam "dari satu sisi zakat adalah bagian dari sadaqah, yaitu $a l$-'usyr yang diwajibkan bagi umat Islam atas tanah non kharaj, dari sisi lain ${ }^{30}$ misalnya jizyah penduduk jazirah Arab tidak dapat diterimà. Mereka harus memilih Islam atau dibunuh, tanah mereka berstatus 'usyur. Dengan demikian, pendapat Ibn Adam bahwa al-'usyur, zakat dan shadaqah mengandung makna yang saling berdekatan, atau satu sama lain saling berhubungan. Pendapat ini sangat umum di kalangan beberapa fuqaha'.

Meskipun zakat merupakan simbol dan memperkuat solidaritas bersama antara sesama muslim, namun zakat itu sendiri merupakan aktifitas simbolik pada waktu tertentu sehingga tidak ada kepastian jumlah nominalnya seperti halnya al-kharaj dan al-jizyah. Yahya Ibn Adam menyebutkan zakat, menyusul ghanima $h$ dan seperlima di antaranya untuk Allah. Setelah itu Ibn Adam menyebutkan ratio zakat misalnya al-'usyr untuk zakat hasil pertanian dari sawah tadah hujan, dan hasil pertanian yang diairi oleh usaha manusia adalah nishfu al-usyr". ${ }^{31}$ Nash ini mengandung konsep dualistis yaitu hasil produksi alam, dan hasil kerja manusia: hasil pertanian yang diperoleh secara alami, zakatnya lebih besar dari pada hasil pertanian yang diperoleh dengan usaha manusia, ini dari satu sisi. Dari sisi lain, terdapat pembedaan keadaan individu masing-masing calon muzakki. Ini merupakan permasalahan yang selalu diulang dalam karya Ibn Adam ketika menghitung ratio zakat hasil bumi, hasil produksi, hewan ternak dan lain-lain.

Oleh karena itu tidaklah kebetulan jika dalam pembahasan tentang zakat, Ibn Adam memunculkan dua istilah yaitu al-qîmah dan al-nafaqah. Padahal pemunculan kedua istilah tersebut pada saat mendiskusikan al-kharaj relatif jarang, kecuali pada rincian hitungan awal jumlah nominal yang harus dibayar setelah pengurangan (diskon) untuk memenuhi kebutuhan hidup kaum zimmi.

${ }^{28}$ Ibid., hal. 49

${ }^{29}$ Pembahasan zakat dalam karya-karya lazimnya setelah pembahasan shalat.

${ }^{30}$ Ibn Adam, op. cit., hal. 78.

${ }^{31}$ Ibid., hal. 80-84. 
Bersamaan dengan perbedaan antara pajak tanah (al-kharaj al-ardh) dan zakat tanah (zakat al-ardh), ditemukan pula adanya peluang untuk menggAbûngkan keduanya. Disebutkan oleh Ibn Adam bahwa jika seorang muslim menyewa sebidang tanah kharaj: ada pendapat bahwa al-kharaj dibebankan kepada pemilik tanah dan zakat dibebankan kepada penyewa tanah yang muslim. Dalam waktu yang sama ada pendapat lain yang mengatakan bahwa kharaj maupun zakat dibebankan kepada penyewa. ${ }^{32}$ Bahkan ada kasus bahwa al-kharaj masuk dalam shadaqah khusus bagi suku (kabilah) bani Taghlab yang beragama Kristen yang tanahnya berstatus ' $u$ syuriyah. Jadi tidak terkena al-kharaj, tetapi dha'fu al-'uayr (kelipatan dari 'usyur). ${ }^{33}$

Konsep shadaqah dan jizyah semakin saling memasuki pada kasus bea cukai yang diwajibkan bagi barang perdagangan (masalah ini juga kita temukan dalam karya Abû Yûsuf). Tarip bea cukai yang dikenakan kepada kaum muslim adalah rub' 'ul usyr, dan bagi kaum zimmi (yang tinggal di Dâr al-Islâm) nishfu al-'usyr, dan pedagang yang datang dari Dar al-harb dikenakan al-'usyr. Tarip beacukai ini tidak bersifat sukarela seperti halnya zakat, melainkan mirip dengan dharibah (pajak). Akan tetapi dihitung atas dasar ajza' min al-'usyr (bagian-bagian 'usyr) yang diwarnai dengan pewarnaan shadaqah seperti sudah disebutkan sebelumnya. Shadaqah adalah pemberian atas dasar solidaritas di kalangan umat Islam. Tentu saja, kedekatan sepersepuluh pajak ('asyr almakas) dari sepersepuluh shadaqah lebih kuat bagi pengusaha muslim. Perbedaan antara muslim dengan non muslim dalam ratio pajak merupakan perbedaan yang bersifat kuantitatif bukan kualitatif (bagian-bagian dari al-'usyr). Hanya saja Ibn Adam memposisikan pajak bagi kaum zimmi dan kaum harbî "sama kedudukannya dengan al-fa' $i$ karena konsekuensi dari perdamaian, jadi kedudukannya tidak sama dengan shadaqah, melainkan sama dengan al-kharaj dan al-jizyah"34.

Sepertinya Yahya Ibn Adam memfokuskan kekuasaan pada penguasa (imam) dengan cara ekstrim dibandingkan Abû Yûsuf. Artinya penguasa diberi kebebasan penuh untuk melakukan sesuatu di daerah taklukkan. ${ }^{35}$ Dalam waktu yang sama beliau juga membebaskan hak kepada orang untuk menggali sumur di tempat-tempat sekitar daerah taklukkan tersebut. ${ }^{36}$

Ide sebagian misi ekonomi menurut Ibn Adam melekat pada alat-alat negara atau pemerintah, khususnya ketika melakukan perintah untuk bercocok tanam pada tanah yang tidak diinginkan oleh seseorang. ${ }^{37}$ Namun dalam konteks penggarapan

\footnotetext{
${ }^{32}$ Ibid, hal. 118.

${ }^{3}$ Ibid., hal. 15, 16, 46-47.

${ }^{34}$ Ibid, hal. 10-11.

${ }^{35}$ Ibid., hal. 4, 5 dan 31 .

${ }^{36}$ Ibid., hal. 64.

${ }^{37}$ Ibid, hal. 44-45.
} 
tanah kosong, Ibn Adam mengutamakan masyarakat secara personal. Merekálah yang harus berinisiatif dalam melakukan pekerjaan ini, bukan inisiatif dari alat pemerintah kecuali untuk melindungi kekayaan umum. Dia menghubungkan misi ekonomi dengan misi politik bagi aparat penguasa, yaitu mengantisipasi dan mencegah agar tidak terjadi kekacauan dan perselisihan internal yang dapat menimbulkan priksi di kalangan umat Islam. Mungkin dapat disimpulkan bahwa pendapat Ibn Adam tentang kepemilikan bersama atas kekayaan dasar (musytarakât al-tsarwat al-asâsiyyah) untuk menjamin agar tidak terjadi keretakan di dalam tubuh umat Islam. Sehubungan dengan ini, lagi-lagi Ibn Adam mengutip riwayat yang mengatakan bahwa Umar Ibn al-Khattab membagi-bagi tanah Sawad, kemudian terjadi perselisihan yang dapat mengancam persatuan umat Islam. akhirnya Umar menarik tanah-tanah tersebut dari umat Islam (sebagai pemilik baru). ${ }^{38}$

Tema kekuasaan kemudian menggiring Ibn Adam mendiskusikan kepemilikan. Terdapat perbedaan antara kepemilikan harta bergerak (tidak tetap) dengan kepemilikan harta tidak bergerak (tetap) seperti bangunan dan lain-lain. Sepertinya kepemilikan terhadap barang yang bergerak tidak mengalami persoalan serius, karena hak bagi pemilik harta tersebut sangat permanen walaupun bukan dalam arti mutlak mengingat ada kewajiban zakat dari satu sisi, dan pajak dari sisi lain. Akan tetapi kepemilikan terhadap harta tetap termasuk tanah mengalami persoalan dan menimbulkan polemik yang besar.

Ide yang mengatakan bahwa barang siapa menggarap lahan kosong dan irigasinya atau menjadikannya lahan produktif, maka orang itu berhak atas tanah tersebut "barang siapa menggarap lahan mati maka ia mempunyai hak atas tanah tersebut. ${ }^{39}$

Akan tetapi menggarap tanah tidak selalu dengan cara bertanam, melainkan juga dengan cara mendirikan bangunan di atasnya atau dengan sekadar memagarnya. ${ }^{40}$ Masalah ini menunjukkan bahwa ihyâ' al-mawâd tidak mesti dengan menanam atau mendirikan bangunan, tetapi cukup juga dengan memberi tanda.

Terakhir dalam tulisan ini, memaparkan bahwa hak kepemilikan atas tanah menurut Ibn Adam tunduk pada sejumlah syarat, jadi tidak bersifat mutlak. Namun yang paling penting adalah syarat yang berhubungan dengan pengelolaan tanah seperti menanaminya dan lain sebagainya. Sehubungan dengan ini, Ibn Adam menyebutkan riwayat dari Abdullah Ibn Abi Bakar bahwa Nabi Muhammad saw. memberikan tanah yang luas kepada Bilal Ibn Haris al-Muzanî. Bilal tidak menanami keseluruhan tanah tersebut, maka Umar berusaha meyakinkan Bilal agar melepas sebagian tanah itu. Temyata

${ }^{38} I$ bid., hal. $29-30$.

${ }^{39}$ Ibid., hal.60, 61 .

${ }^{40} \mathrm{Jbid}$., hal. 66. 
Bilal enggan melepas tanah tersebut. Tetapi karena Bilal tidak mampu menggarapnya, maka tanah itu pun dibagi-bagi kepada sejumlah umat Islam.

Dari pendapat-pendapat tersebut dapat disimpulkan bahwa Yahya Ibn Adam tidak hanya mengedepankan konsep ekonomi an sich, tetapi juga konsep keagamaan dan militer.

\section{E. Penutup}

- Abû Yûsuf dan Ibn Adam memiliki perbedaan metodologis dalam menulis alKharaj. Abû Yûsuf lebih rasional dalam mengungkapkan dalil-dalil, dan rumusan fiqh ekonominya lebil realistis dan independen. Sementara Ibn Adam memperkuat fiqh ekonominya dengan argumen-argumen tekstual mengacu kepada ahâadits dan ah́hâts tanpa melakukan kritik eksternal dan internal terhadapnya.

al-Kharaj, menurut mereka mengandung makna umum yaitu sumber-sumber pendapatan negara, dan makna khusus yaitu pajak tanah. al-Kharaj dan al-jizyah dibebankan kepada kaum zimmi, sementara kaum muslim diwajibkan mengeluarkan zakat sebagai simbol solidaritas antar sesama muslim.Namun demikian, al-kharaj,jizyah dan zakat menurut Ibn Adam mengandung makna yang berdekatan. Akan tetapi sifatsifat inhern pada zakat menafikan persamaan zakat dengan al-kharaj dan al-jizyah.

\section{DAFTAR PUSTAKA}

Adam, Yahya Ibn, 1979, Kitâb al-Kharaj, tahqih Ahmad Muhammad Syakir, Beirut Dâral-Ma'rifah.

Junaidal, Hamad Abdurrahman al-, 1406, Manâhij al-Bâhitsîn fi al-Iqtishâd al-Islâmî, Syarikah al-'Ubaikan li al-Thaba'ati wa al-Nasyr.

Dûri, Qahthan Abdurrahmân al-, 1974, al-Ihtikâr wa Atsaruhu fí al-Fiqh al-Islâmî, Cet. I, Bagdad: Mathba'ah al-Ummah.

Husyairi, Ahmad al-, 1986, al-Siyasah al-Iqtishadiyah wa al-Nudlûm al-Mâliyyah $f i$ al-Fiqh al-Islânnî, Beirut: Dâr al-Kitâb al-'Arabî, Cet. I.

Ibrâhîm, Abû Yúusuf Ya'qub Ibn, 1979, al-Kharaj, Beirut: Dâr al-Ma'rifah. 
Praja, Juhaya S., Perkembangan Pemikiran Ekonomi Syariah, bahan kuliah Pendekatan dalam Pengkajian Islam Magister Studi Islam Universitas Islam Indonesia Yogyakarta.

Qol'aji', Muhammad Rowas dan Qunaibi, Hamid Sodiq, 1988, Mu'jam lugât alFuqahâ', Arabi Inklizi, cet. II, Beirut: Dâr al-Nafâ' is.

Sa'ad, Ahmad Sodiq, 1979, Târîkh Meshr al-Ijtimâ'i al-Iqtishâdî̀, Beirut: Dâr Ibn Khaldun.

Salâm, Abû 'Ubaid al-Qâsim Ibn, 1353 H, al-Amwâl, tahqîq Muhammad Hamid alFaqy, Kairo: Dâr al-Kutub al-Mishriyyah.

Yasin, Najman, 1988, Thathawwuru al-Audha' al-Iqtish^adiyyahfi 'Ashrial-Risâlah wa al-Râsyidín, Mosul: Bait al-Mosul, Jâmi'at al-Mosul. 